\title{
STRATEGI PERTUMBUHAN GEREJA MELALUI PENDIDIKAN ANAK USIA DINI
}

\author{
Elisabet Selfina Dasong \\ sttjaffraymakassar@yahoo.co.id
}

\begin{abstract}
ABSTRAK
Sesuai dengan permasalahan yang ada, maka tujuan penulisan karya ilmiah ini adalah: Pertama, mengintegrasikan kurikulum PAUD khususnya dalam pendidikan TK Kristen sebagai jenjang pendidikan formal yang tertuang dalam Kegiatan Belajar Mengajar (KBM) dengan iman Kristen. Kedua, menggunakan kurikulum PAUD dalam jenjang pendidikan formal yaitu TK Swasta Zion di mana GKKA-UP sebagai penyelenggara bagi strategi pertumbuhan gereja lokal dapat mendukung pertumbuhan gereja khususnya gereja pemilik institusi PAUD, dalam hal ini institusi dalam jenjang pendidikan formal yaitu TK Kristen Zion yang dimiliki oleh GKKA-UP.

Adapun metode yang digunakan dalam penulisan karya ilmiah ini adalah: Pertama, penulis melakukan kajian pustaka yaitu dengan mengumpulkan data tentang pendidikan anak usia dini dan korelasinya bagi perkembangan iman serta kerohanian anak, juga bagaimana PAUD menjadi strategi pertumbuhan gereja. Kedua, melalui wawancara ke obyek kajian. Ketiga, melalui angket terbuka (open ended questions) yang disebarkan kepada alumni TK Swasta Zion dan guru-guru TK tersebut, serta kepada orang tua murid TK Kristen Zion.

Adapun kesimpulan dari hasil penelitian dan pembahasan karya ilmiah ini adalah: Pertama, gereja dapat bertumbuh melalui dua cara, yaitu penginjilan dan pemuridan. Penginjilan adalah pemberitaan kabar baik kepada orang yang belum percaya kepada Tuhan Yesus agar mereka menjadi percaya dan kemudian menjadi anggota tubuh Kristus, yaitu gerejaNya. Pemuridan adalah pengajaran bagi orangorang percaya agar mereka bertumbuh dan berfungsi dengan baik sebagai anggota tubuh Kristus. Kedua, ada berbagai metode pertumbuhan gereja melalui penginjilan. Salah satunya adalah melalui sarana pendidikan formal, yaitu sekolah yang diselenggarakan oleh gereja. Ketiga, PAUD pada jenjang pendidikan formal yaitu TK, dalam hal ini TK Kristen yang diselenggarakan oleh gereja lokal dapat dijadikan sebagai salah satu strategi bagi pertumbuhan gereja. Keempat, anak usia dini yang mengikuti pendidikan TK, yaitu usia 4-6 tahun adalah ladang misi yang luar biasa. Karakteristik murid TK sangat terbuka terhadap pengajaran tentang kasih Yesus/Allah.
\end{abstract}

Kata kunci: Strategi, pertumbuhan gereja, pendidikan, anak usia dini 


\section{PENDAHULUAN}

\section{Latar Belakang Masalah}

Pada saat ini dunia pendidikan di Indonesia mulai memberi perhatian yang lebih serius bagi pendidikan anak usia dini, karena pada masa ini diyakini bahwa potensi kecerdasan anak dan dasar-dasar perilaku seorang anak terbentuk. Berdasarkan hasil penelitian bagian neurologi terbukti bahwa 50\% kapasitas kecerdasan manusia terbentuk pada kurun waktu empat tahun pertama sejak kelahirannya, dan pada saat anak berusia 8 tahun telah terbentuk 80\% kapasitas kecerdasannya. Untuk pertumbuhan fungsional sel-sel sarafnya diperlukan situasi pendidikan yang dapat mendukung agar pertumbuhan tersebut dapat berjalan dengan baik. ${ }^{1}$ Itulah sebabnya sehingga perlu perhatian yang sungguh bagi Pendidikan Anak Usia Dini (PAUD). Dukungan untuk PAUD sangatlah diperlukan dari lingkungan keluarga, sekolah, dan masyarakat dalam hal ini termasuk juga gereja. Karena rentang usia dini sangat penting, maka pada masa usia ini disebut juga usia emas (the golden age). Batasan usia dini adalah usia antara $0-8$ tahun. ${ }^{2}$ Usia dini adalah usia di mana terjadi pertumbuhan dan pembentukan bukan saja sel-sel saraf, namun juga kepribadian anak termasuk juga segi moral dan kerohaniannya yang akan menentukan kehidupannya pada masa yang akan datang. Dapatlah dikatakan bahwa usia dini adalah usia yang sangat berharga dibandingkan golongan usia yang lain.

Anak usia dini, yaitu usia 0-8 tahun adalah usia yang paling penting untuk menanamkan nilai-nilai moral dan kerohanian. Apa yang ditanamkan pada usia dini akan membentuk moral dan kerohanian anak hingga dewasa kelak.

Usia dini adalah usia pembentukan baik emosi, mental, fisik, bahkan kerohanian anak, maka gereja perlu mengambil kesempatan ini, yaitu memperhatikan PAUD. Ahli pendidikan yaitu Yussen dan Santrock berpendapat, "Kemampuan sosialisasi anak sangat terkait dengan orangorang di sekeliling anak yang disebut agen sosial, yaitu setiap orang yang berhubungan dengan seorang anak, misalnya ayah dan ibunya, pengasuh, teman sebaya, guru dan keluarga lainnya yang mempengaruhi cara anak

${ }^{1}$ Iva Noorlaila, Panduan Lengkap Mengajar PAUD (Yogyakarta:PINUS BOOK PUBLISHER, 2010), 17. Hal senada juga disampaikan dalam buku yang ditulis Ahmad Susanto, Perkembangan Anak Usia Dini: Pengantar dalam Berbagai Aspeknya (Jakarta:Kencana, 2011), 22.

${ }^{2}$ Beberapa buku mendukung bahwa usia dini adalah usia emas (the goleden age), antara lain: Noorlaila, 15. Pandangan yang sama dalam buku Jamal Ma'mur Asmani, Manajemen Strategis Pendidikan Anak Usia Dini (Jogjakarta:DIVA Press, 2009), 39; Dyah Ayuningsih, Psikologi Perkembangan Anak (Yogyakarta:Pustaka Larasati, n.d.), 94. 
berperilaku." 3 Senada dengan pendapat Yussen dan Santrock, Feeney menyatakan bahwa, "Sebagian besar nilai-nilai dan pelaksanaa program pendidikan anak tumbuh dari nilai anak dalam suatu masyarakat yang diadopsi secara turun temurun, di antaranya juga dipengaruhi oleh pemimpin agama, pembaharu masyarakat, dan pendidik di masa sebelumnya." 4 Dari pendapat para ahli pendidikan ini, dapat disimpulkan bahwa PAUD dipengaruhi oleh faktor-faktor yang kompleks antara lain lingkungan keluarga, sekolah, masyarakat-dalam konteks tulisan ini adalah gereja-dan faktor budaya atau kebiasaan hidup. Dengan demikian, gereja dapat mengambil kesempatan ini untuk mempengaruhi seorang anak agar dapat menjadi anggota gereja yang tangguh di kemudian hari.

Rosalind Lim-Tan dalam materi kuliah Together for Children untuk program Holistic Child Development menuliskan,

The most immediate circle is the environment where most interaction with the child takes place. This circle consists of family, friends, school, immediate community, and the religious community where the child belongs. This is also the circle where the child is (normally) first introduced to issues of faith and where early foundations of belief (or disbelief) are laid. The home and the faith community play a major role in forming faith. This circle is the most influential of all the circles and where the child feels safest. $^{5}$

Pendapat ini menyatakan bahwa lingkungan pertama anak yang sangat mempengaruhinya adalah keluarga, sekolah dan komunitas iman seperti gereja tempat anak tersebut biasa beribadah. Dari lingkungan inilah anak pertama mengenal dan belajar iman Kristen. Artinya bahwa PAUD sangat berpengaruh bagi pembentukan iman dan kerohanian seorang anak hingga dewasa, karena pada usia ini adalah usia awal anak mengenal iman Kristen.

Sayangnya gereja belum memanfaatkan dengan maksimal PAUD sebagai bagian dari strategi pertumbuhan gereja. Bahkan buku referensi atau bahan bacaan mengenai strategi pertumbuhan gereja melalui sekolah atau institusi resmi untuk PAUD sangatlah jarang ditemukan. Buku-buku tentang PAUD sebagian besar, kalau tidak bisa dikatakan

\footnotetext{
3 Jamal Ma'mur Asmani, Manajemen Strategis Pendidikan Anak Usia Dini (Jogjakarta:DIVA Press, 2009), 26.

${ }^{4}$ Ibid.

${ }^{5}$ Rosalind Lim-Tan, "Catatan Kuliah Together for Children Together for Children Training for Trainers Module 1" (MBTS Holistic Child Development Institute, July 12, 2011), 58 .
} 
seluruhnya ditulis oleh ahli-ahli pendidikan atau pengamat pendidikan sekuler sehingga dapat dipastikan pandangan dan tulisannya adalah berisi pemikiran sekuler. Ketika gereja dapat menjadikan PAUD sebagai bagian strategi pertumbuhan gereja, maka program PAUD dapat bersinergi dengan gereja. Institusi PAUD yang paling dimungkinkan untuk bersinergi dengan gereja adalah institusi PAUD yang dimiliki oleh gereja. Dalam hal gereja sebagai pemiliknya, maka institusi PAUD yang dimaksud adalah institusi pendidikan dalam jalur formal yaitu Taman Kanak-kanak (TK). ${ }^{6}$

Namun dalam pelaksanaannya perlu bersikap bijaksana khususnya dalam menyikapi Undang-Undang (UU) Sisdiknas, agar kerja sama gereja dan sekolah atau lembaga Kristen penyelenggara PAUD tidak menjadi masalah di kemudian hari yaitu dituding memaksa anak memeluk agama tertentu. ${ }^{7}$ Untuk itu perlu disediakan kurikulum yang sesuai dengan perkembangan dan kebutuhan anak usia dini termasuk juga bagi pertumbuhan iman dan kerohanian anak dan di saat yang sama kurikulum PAUD tidaklah bertentangan dengan kurikulum yang diakui oleh pemerintah. Kurikulum yang demikian memang diakui sulit untuk dilakukan, yaitu kurikulum praktis yang mengintegrasikan iman Kristen dengan PAUD secara umum.

Pemikiran-pemikiran di atas menjadi dasar bagi penulis untuk mengangkat sebuah tulisan yang berjudul "Strategi Pertumbuhan Gereja Melalui Pendidikan Anak Usia Dini." PAUD yang dimaksud adalah PAUD yang dimiliki oleh gereja, yaitu PAUD dalam jenjang pendidikan formal, yang dikenal sebagai Taman Kanak-Kanak (TK) Kristen. Untuk itu penulis akan melakukan kajian bagaimana PAUD dapat dijadikan strategi pertumbuhan gereja dan obyek yang penulis kaji adalah TK Zion, yaitu TK yang dimiliki dan dikelola oleh Gereja Kebangunan Kalam Allah Jemaat Ujung Pandang (GKKA-UP) lewat Yayasan Pendidikan Bukit Zion.

\section{Masalah Pokok}

Dari pemikiran-pemikiran yang dibahas dalam latar belakang masalah di atas, ada beberapa pokok masalah yang perlu ditelaah dalam tulisan ini, yaitu:

Pertama, bagaimana kurikulum PAUD khususnya dalam pendidikan TK Kristen sebagai jenjang pendidikan formal yang tertuang dalam Kegiatan Belajar Mengajar (KBM) dapat berintegrasi dengan iman Kristen? Kedua, bagaimana menggunakan kurikulum PAUD dalam

${ }^{6}$ Sistem Pendidikan Nasional, DEPDIKNAS, 2008.

${ }^{7}$ Daniel Nuhamara, Pembimbing PAK (Jawa Barat:Jurnal Info Media, 2007), 111. 
jenjang pendidikan formal yaitu TK Swasta Zion di mana GKKA-UP sebagai pemiliknya bagi strategi pertumbuhan gereja tersebut?

\section{Tujuan Penulisan}

Dari pemaparan pokok masalah di atas, maka penulis membahas dua tujuan penulisan dari karya ilmiah ini, Pertama, mengintegrasikan kurikulum PAUD khususnya dalam pendidikan TK Kristen sebagai jenjang pendidikan formal yang tertuang dalam Kegiatan Belajar Mengajar (KBM) dengan iman Kristen. Tujuan praktisnya di mana dapat disusun kurikulum yang sesuai bagi PAUD yang dapat memenuhi kebutuhan perkembangan anak sekaligus juga pembentukan iman dan kerohanian anak. Kedua, menggunakan kurikulum PAUD dalam jenjang pendidikan formal yaitu TK Swasta Zion di mana GKKA-UP sebagai penyelenggara bagi strategi pertumbuhan gereja lokal. Tujuan yang kedua ini membahas bahwa melalui kurikulum PAUD yang tertuang dalam KBM dapat mendukung pertumbuhan gereja khususnya gereja pemilik institusi PAUD, dalam hal ini institusi dalam jenjang pendidikan formal yaitu TK Kristen Zion yang dimiliki oleh GKKA-UP.

\section{Manfaat Penulisan}

Adapun manfaat penulisan yang diharapkan dari penulisan karya ilmiah ini adalah: Pertama, kajian kurikulum PAUD dalam meningkatkan iman dan kerohanian kiranya dapat menjadi referensi dalam mengembangkan kurikulum PAUD dalam pendidikan Kristen. Kedua, pengembangan PAUD dalam pendidikan yang diselenggarakan oleh suatu gereja kiranya dapat terintegrasi sehingga dapat menjadi suatu strategi dalam pertumbuhan gereja. Ketiga, untuk menyelesaikan pendidikan program pascasarjana (MA di bidang Pelayanan Anak atau Holistic Child Development) di Sekolah Tinggi Theologia Jaffray dan tulisan ini dapat dimanfaatkan bagi mereka yang tertarik mengembangkan PAUD di gereja masing-masing.

\section{Metodologi Penelitian}

Desain penulisan karya ilmiah ini menggunakan penelitian kualitatif, di mana teknik pengumpulan data dilakukan sebagai berikut,

Pertama, penulis melakukan kajian pustaka yaitu dengan mengumpulkan data tentang pendidikan anak usia dini dan korelasinya bagi perkembangan iman serta kerohanian anak, juga bagaimana PAUD menjadi strategi pertumbuhan gereja. Kedua, melalui wawancara ke obyek kajian. Wawancara dilakukan kepada pihak TK Kristen Zion, dalam hal ini kepala sekolah dan Yayasan Bukit Zion dan pemimpin gereja lokal pemilik TK Kristen, yaitu GKKA-UP, dalam hal ini adalah 
pemimpin rohani gereja dan atau majelis gereja. Wawancara dilakukan untuk mengenal TK Kristen Zion, tujuan pendirian TK tersebut oleh gereja dan kegiatan operasional sekolah yaitu KBM TK Kristen Zion. Tujuannya untuk mendapatkan gambaran sejauh mana TK telah bersinergi dengan gereja dalam strategi pelayanan gereja. Ketiga, melalui angket terbuka (open ended questions) yang disebarkan kepada alumni TK Swasta Zion dan guru-guru TK tersebut, serta kepada orang tua murid TK Kristen Zion. Tujuannya untuk mendapatkan data yang lebih mendalam tentang peran PAUD dalam meningkatkan kerohanian anak dan bagaimana korelasinya dengan pertumbuhan gereja lokal.

\section{Batasan Penulisan}

Rentang usia PAUD adalah mulai dari $0-8$ tahun. Namun karena keterbatasan dalam penulisan karya ilmiah ini, penulis membatasi usia PAUD pada usia 4 - 6 tahun, yaitu pada usia anak mengikuti jenjang pendidikan formal PAUD di tingkat TK. ${ }^{8}$ Begitu juga dengan kurikulum PAUD. Kurikulum PAUD yang akan dibahas adalah kurikulum PAUD pada aspek nilai-nilai moral dan agama. Karena aspek ini adalah aspek yang paling berhubungan dengan iman Kristen dan pertumbuhan gereja. Juga penulisan karya ilmiah ini hanya membahas PAUD pada jenjang pendidikan formal yaitu TK. Dalam hal ini TK Swasta Zion yang bernaung atau dimiliki oleh GKKA-UP.

${ }^{8}$ Asmani, Manajemen Strategis Pendidikan Anak Usia Dini, 53. 


\section{METODOLOGI PENELITIAN}

\section{Gambaran Subyek Penelitian}

\section{Sekolah Zion sebagai Sekolah di bawah Naungan GKKA-UP}

Sekolah Zion saat ini terdiri dari TK sampai SMA. Sekolah Zion berdiri tahun 1968 atas inisiatif Pdt. Tze Ying Kwong, dr. Robert Sutjiadi dan Pdt. Iman Santoso. Tze melihat pentingnya pendidikan sudah sejak tahun 1938, sehingga di tahun itu dia telah membuka sebuah sekolah. Tetapi karena terjadi perang di zaman pendudukan Jepang, maka sekolah sempat berhenti lama. Baru pada tahun 1968 sekolah dibuka kembali sampai sekarang yang meliputi jenjang pendidikan PGTK-SD-SMP Zion, dan tahun 2011 dimulai SMA Zion.

Pada mulanya dibuka TK di Jalan Banda No. 1 yaitu memanfaatkan lahan parkir gereja. Setelah TK, juga dibuka SD dan SMP di mana semuanya dipusatkan di Jalan Banda. Pada tahun 1969, Sekolah Zion didaftarkan di bawah nama Yayasan Pendidikan Zion dan sejak tahun 2006 berubah nama menjadi Yayasan Bukit Zion. Kemudian tahun 1985, SMP Zion pindah ke Jalan Sungai Cerekang No. 22 dan TK Zion pindah ke Jalan Sungai Limboto Lorong 38/4-6 dan kedua unit pendidikan itu masih di lokasi yang sama sampai hari ini. Sedangkan untuk SMA dibuka tahun 2011 yang berdomisili di Jalan Wahidin Sudirohusodo No. 93-95 bergabung bersama dengan SD Zion.

Latar belakang berdirinya Sekolah Zion adanya kebutuhan pendidikan sekolah bagi anak-anak berlatar belakang Tionghoa, di mana sejak peristiwa 30 September 1965, pemerintah Orde Baru menutup sekolah-sekolah berlatar belakang Tionghoa. Ketika ormas Tionghoa dilarang, maka gereja yang berlatar belakang Tionghoa tidak dilarang sehingga ini menjadi suatu kesempatan bagi gereja menyediakan sekolah umum. ${ }^{10}$ Sejak pelarangan ini, mengakibatkan orangtua yang berlatar belakang suku Tionghoa segan memasukkan anaknya di sekolah umum atau negeri. Ada keinginan untuk mempertahankan identitas diri tanpa harus menjadi eksklusif. Terlebih dari itu, ada upaya untuk memberikan penaburan berita Injil dan penanaman nilai rohani kepada anak-anak. ${ }^{11}$

\footnotetext{
9 "Sejarah GKKA Indonesia Jemaat Ujung Pandang"; diakses tanggal 2 April 2012;tersedia di http://gkkaupg.blogspot.com/2009/05/sejarah-gkkaujungpandang.html

${ }^{10}$ Lihat Budi Abdiono, "Sekolah Zion Sebagai Salah Satu Strategi Pengembangan Pelayanan di GKKA Indonesia Jemaat Ujungpandang”, Karya ilmiah (Makassar:STT Jaffray Makassar, 2011), 62.

${ }^{11}$ Ibid., 62-63.
} 
Visi dan misi Sekolah Zion adalah sebagai berikut: Visi adalah menjadikan Sekolah Zion sebagai lembaga pendidikan yang bermutu untuk dapat menghasilkan lulusan yang beriman, berilmu, dan berpengabdian. Sedangkan misinya adalah 3 "M" yaitu:1) Menumbuhkan nilai-nilai Kristiani pada peserta didik;2) Memberikan pendidikan yang bermutu pada peserta didik;3) Membentuk peserta didik memiliki jiwa berpengabdian. $^{12}$

Sekolah Zion adalah milik GKKA Jemaat Ujungpandang, di mana pengurus yayasan diangkat oleh gereja dan strukturnya di bawah kemajelisan GKKA Jemaat Ujungpandang. Ini berarti Sekolah Zion adalah bagian integral yang tidak terpisahkan dari visi dan misi gereja, dalam hal ini GKKA-UP. ${ }^{13}$ Saat ini di setiap unit sekolah ditempatkan penginjil sekolah, di samping guru agama. Tujuannya agar ada pelayanan khusus di sekolah, termasuk pelayanan konseling Kristen dan pelayanan rohani kepada anak. Tentunya jika terjadi tindak lanjut pelayanan, di mana anak-anak membutuhkan pelayanan rohani dapat dibawa kepada pelayanan gereja. Jadi semangat pendirian Sekolah Zion adalah bagian dari pekabaran Injil yang dilaksanakan oleh GKKA UP. ${ }^{14}$

\section{Profil Taman Kanak-Kanak Zion}

TK Zion berlokasi di tengah-tengah kota Makassar dan beralamat di Jalan Sungai Limboto Lorong 38 No. 4-6 dengan gedung permanen yang memadai untuk pendidikan TK. Saat ini TK Zion memiliki 197 siswa untuk tahun ajaran 2011/2012. Anak-anak TK yang masuk terdiri Playgroup sebanyak 42 siswa, TK A sebanyak 78 siswa dan TK B sebanyak 77 siswa. Dari segi kepercayaan, anak-anak yang beragama Kristen sebanyak 130 siswa, yang beragama non-Kristen sebanyak 67 siswa. Itu artinya, 66 persen beragama Kristen dan 34 persen beragama lainnya. Umumnya selain beragama Kristen, anak-anak ini beragama Buddha dan Kong $\mathrm{Hu} \mathrm{Cu}$. Pendidikan agama yang diberikan hanya agama Kristen dan kurikulum yang dipakai mengacu kepada kurikulum pemerintah yaitu Kurikulum Tingkat Satuan Pendidikan (KTSP). Kegiatan pendidikan adalah pengajaran di kelas, bermain, dan pengembangan kreativitas anak lainnya. ${ }^{15}$ Jadwal kegiatan sekolah TK Zion adalah dari Senin sampai dengan Sabtu di mana juga diadakan ibadah Kristen pada hari Jumat dan Sabtu. Tujuannya menjadi penumbuhkembangan karakter Kristen bagi anak-anak dan penanaman nilai-nilai Kristen dalam kehidupan anak-anak.

\footnotetext{
${ }^{12}$ Dokumen Sekolah Zion, 2011.

${ }^{13}$ Sesuai dengan apa yang dinyatakan dalam "Akte Pendirian Yayasan Pendidikan Zion, Geredja Kristen Makassar”, Nomor 27, Tanggal 11-11-1969. ${ }^{14}$ Ibid.

${ }^{15}$ Yoseo Fatimah (Kepala Sekolah), Wawancara oleh Penulis, 2 April 2012.
} 
Jumlah alumni TK Zion yang tercatat dari tahun 1979 sampai tahun 2011 sebanyak 2908 orang. Namun tidak ada data tentang profil alumni TK Zion dari segi profesi, begitu pula dari segi keyakinan, apakah mereka tetap aktif di gereja atau tidak dan seterusnya.

Staf pelaksana pendidikan TK Zion terdiri dari kepala sekolah, guru dan staf administrasi. Kepala Sekolah adalah Yoseo Fatimah, SPAK, MA dengan 13 orang guru dan 2 karyawan administrasi. Guru dan dosen rata-rata berpendidikan S1 dan S2 di bidangnya. Semua guru yang ada adalah wanita dan tidak ada pria. Ini disebabkan karena kebutuhan pendidikan TK yang lebih kepada perawatan dan bimbingan kepada anak-anak.

\section{Kurikulum TK Zion}

Adapun kurikulum yang dipakai oleh TK Kristen Zion adalah sebagai berikut: ${ }^{16}$

Tingkat pencapaian perkembangan pada kelompok A ( 4 - 5 tahun)

1. Mengenal Tuhan melalui agama yang dianutnya

2. Meniru gerakan beribadah

3. Mengucapkan doa sebelum dan/sesudah melakukan sesuatu

4. Mengenal berperilaku baik/sopan

5. Membiasakan diri berperilaku baik

6. Mengucapkan salam dan membalas salam

Capaian perkembangan

1. Mengenal ciptaan-ciptaan Tuhan

2. Menyayangi ciptaan Tuhan

3. Mengenal bermacam-macam agama

4. Menyanyikan lagu-lagu keagamaan

5. Mengenal tempat-tempat ibadah

6. Mengenal waktu-waktu beribadah

7. Meniru gerakan ibadah

8. Berdoa sebelum/sesudah melakukan kegiatan.

9. Mengenal perilaku baik/sopan dalam berbicara

10. Mengenal perilaku baik/sopan dalam berpakaian

11. Mengenal perilaku baik/sopan dalam bertingkah laku

12. Memiliki toleransi terhadap sesame

13. Mulai memiliki rasa kepedulian

14. Mulai berperilaku saling hormat menghormati

15. Timbulnya sikap kerja sama dan persatuan

16. Mengucapkan salam dan membalas salam

Indikator

1. Menyebutkan ciptaan-ciptaan Tuhan

\footnotetext{
${ }^{16}$ Dokumen Kurikulum TK Zion, 2011.
} 
2. Memberi makanan pada hewan, menyirami tanaman, menyayangi teman

3. Menyebutkan macam-macam agama dan hari-hari besar agama

4. Menyanyikan lagu-lagu keagamaan yang sederhana

5. Menyebutkan tempat-tempat ibadah

6. Menyebutkan waktu-waktu beribadah

7. Meniru pelaksanaan kegiatan ibadah secara sederhana, seperti berdoa, memuji Tuhan

8. Berdoa sebelum dan sesudah melakukan kegiatan

9. Berbicara/berbahasa baik/sopan dengan sesame teman dan dengan orang dewasa

10. Berpakaian rapi di rumah, sekolah dan disesuaikan dengan keperluan

11. Tidak menganggu teman

12. Memiliki toleransi dan rasa dermawan terhadap sesame

13. Meminjamkan miliknya dengan senang hati, menggunakan barang orang lain dengan hati dan mau berbagi

14. Mau menghormati teman, guru, orang tua atau orang dewasa lainnya dan mau mengalah

15. Suka menolong, membantu dan mau bekerja sama dengan teman

16. Membiasakan diri mengucapkan salam dan membalas salam

Kelompok B (usia 5 - 6 tahun)

Tingkat pencapaian perkembangan

1. Mengenal agama yang dianutnya

2. Membiasakan diri beribadah

3. Memahami perilaku mulia

4. Membedakan perilakuk baik dan buruk

5. Mengenal ritual dan hari besar agama

6. Menghormati agama orang lain

Capaian perkembangan

1. Mengenal macam-macam agama

2. Mengenal tempat-tempat ibadah

3. Mengenal kitab suci agama yang dianut

4. Terbiasa melakukan ibadah sesuai aturan menurut keyakinan

5. Terbiasa berperilaku sopan santun

6. Terbiasa berperilaku saling hormat

7. Memiliki perilaku mulia

8. Memberikan perbuatan baik dan buruk

9. Melakukan kegiatan yang bermanfaat

10. Mengenal ritual dan hari besar agama

11. Menghormati agama orang lain

Indikator 
1. Menyebutkan macam-macam agama yang ada di Indonesia

2. Menyebutkan agama yang dianut

3. Menyanyi lagu-lagu keagamaan

4. Bersyair yang bernafaskan agama

5. Menyebutkan tempat-tempat ibadah

6. Menyebutkan macam-macam kitab suci.

7. Menyebutkan kitab suci yang dianut

8. Berdoa sebelum dan sesudah melakukan kegiatannya

9. Melaksanakan kegiatan ibadah

10. Berbuat baik terhadap semua makhluk Tuhan

11. Berbicara sopan

12. Menyapa teman dan orang lain

13. Berpakaian rapi dan sopan

14. Selalu mengucapkan terima kasih jika memperoleh sesuatu

15. Menghormati guru, orang tua dan orang yang lebih tua

16. Mendengarkan dan memperhatikan teman berbicara

17. Mau memohon dan member maaf

18. Senang bermain dengan teman

19. Bersikap jujur

20. Suka menolong

21. Menyebutkan mana yang benar dan yang salah pada suatu persoalan

22. Menunjukkan perbuatan yang benar dan salah

23. Menyebutkan perbuatan yang baik dan buruk

24. Melakukan perbuatan-perbuatan yang baik pada saat bermain

25. Melakukan kegiatan yang bermanfaat pada saat dibutuhkan

26. Memelihara kebersihan lingkungan

27. Berperilaku hidup hemat

28. Menyebutkan hari-hari besar keagamaan

29. Terlibat dalam acara keagamaan

30. Menghormati teman yang sedang melakukan ibadah

31. Dapat hidup berdampingan dengan teman yang beragama lain

32. Menghormati hari besar agama lain.

Kurikulum yang dicatat di atas adalah khusus kurikulum mengenai aspek pengembangan nilai-nilai moral dan agama.

\section{Populasi dan Sampel}

Dalam penelitian kualitatif populasi dan sampel adalah sama. Maka penulis akan menjabarkan populasi dan sampel yang akan diteliti: Pertama, penyelenggara pendidikan yaitu majelis GKKA UP yang terdiri dari gembala, penginjil, diaken dan pengurus Yayasan Bukit Zion. Kedua, pelaksana pendidikan yaitu kepala sekolah dan para guru TK Zion di mana ada 14 orang yang akan dijadikan populasi penelitian. Ketiga, 
pengguna pendidikan yaitu beberapa orang tua murid TK Zion dan juga alumni TK Zion yang saat ini menjadi jemaat GKKA UP.

\section{Teknik Pengumpulan Data}

Desain penulisan karya ilmiah ini menggunakan penelitian kualitatif. Untuk mencapai tujuan penulisan, maka ada beberapa langkah pengumpulan data penelitian: Pertama, penulis melakukan kajian pustaka yaitu dengan mengumpulkan data tentang pendidikan anak usia dini dan korelasinya bagi perkembangan iman serta kerohanian anak, juga bagamana PAUD menjadi strategi pertumbuhan gereja. Dengan banyaknya bahan PAUD, maka penulis memfokuskan diri kepada PAUD dan kerohanian anak serta bagaimana strategi pembelajaran di TK menjadi alat pertumbuhan gereja. Kedua, melalui wawancara ke obyek kajian. Wawancara dilakukan kepada pihak TK Kristen Zion, dalam hal ini kepala sekolah dan Yayasan Bukit Zion dan pemimpin gereja lokal pemilik TK Kristen, yaitu GKKA-UP, dalam hal ini adalah pemimpin rohani gereja dan atau majelis gereja. Wawancara dilakukan untuk mengenal TK Kristen Zion, tujuan pendirian TK tersebut oleh gereja dan kegiatan operasional sekolah yaitu KBM TK Kristen Zion. Tujuannya untuk mendapatkan gambaran sejauh mana TK telah bersinergi dengan gereja dalam strategi pelayanan gereja. Ketiga, melalui angket terbuka (open ended questions) yang disebarkan kepada mejelis gereja GKKA-UP, anggota Yayasan Bukit Zion, alumni TK Swasta Zion dan guru-guru TK tersebut, serta kepada orang tua murid TK Kristen Zion. Tujuannya untuk mendapatkan data yang lebih mendalam tentang peran PAUD dalam meningkatkan kerohanian anak dan bagaimana korelasinya dengan pertumbuhan gereja lokal.

\section{Analisis Data dan Pembahasan}

Setelah data terkumpul, maka penulis akan melakukan analisis data dan pembahasan secara kualitatif, di mana dilakukan analisis sebagai berikut: Pertama, melakukan kategorisasi data (coding) dengan mengelompokkan jawaban yang sama atau sejenis dalam rumpun tema yang sama. ${ }^{17}$ Semua jawaban dikategorisasi dan diurut berdasarkan jawaban yang terbanyak sampai ke yang terendah. Pokok yang dibahas adalah soal integrasi PAUD dengan iman Kristen serta kaitan dengan strategi pertumbuhan GKKA-UP. Kedua, melakukan deskripsi pembahasan atas jawaban-jawaban yang diberikan kepada obyek penelitian. Deskripsi pembahasan dilakukan tanpa penafsiran, namun memberikan kalimat-kalimat deskriptif. Untuk mendapatkan akurasi

\footnotetext{
${ }^{17}$ William Wiersma \& Stephen G. Jurgs, Research Methods in Education, Eight ed. (USA:Pearson, 2005), 217.
} 
deskripsi, penulis akan melakukan wawancara lebih lanjut (in depth interview) untuk menemukan jawaban yang tepat. Ketiga, melakukan komparasi data yaitu membandingkan jawaban dari ketiga fihak, yang dalam hal ini fihak penyelenggara, fihak pelaksana dan fihak pengguna. Kegunaan komparasi untuk menemukan sinkronisasi jawaban maupun perbedaan terhadap pokok subyek yang sama yang dianalisis. Keempat, melakukan interpretasi data yang dilakukan untuk memberikan tafsiran data seakurat mungkin sehingga menjadi masukan baik bagi TK Zion maupun GKKA UP.

\section{ANALISIS DATA DAN HASIL PENELITIAN}

\section{Profil Subyek Penelitian}

Adapun angket terbuka yang diberikan kepada pihak penyelenggara yaitu majelis gereja GKKA-UP dan anggota Yayasan Bukit Zion sebanyak 42 orang. Kemudian angket yang telah diisi dan dikembalikan sebanyak 20 orang. Sedangkan kepada pihak pelaksana, yaitu kepala sekolah dan guru-guru TK Zion sebanyak 14 orang, angket yang telah diisi dan dikembalikan sebanyak 10 orang. Angket terbuka juga disebarkan kepada pihak pengguna, dalam hal ini adalah orang tua murid TK Zion dan alumni TK Zion. Angket yang diisi dan berhasil dikembalikan hanya berasal dari alumni TK Zion, yaitu sebanyak 10 orang. Kemudian untuk mendapatkan data dari pihak orang tua murid, penulis melakukan wawancara kepada dua orang tua murid yang berhasil ditemui. Profil dari subyek penelitian dapat digambarkan sebagai berikut:

Tabel 01. Profil Subyek Penelitian

\begin{tabular}{|l|c|}
\hline Profil Subyek & Jumlah \\
\hline $\begin{array}{l}\text { Majelis gereja GKKA-UP dan anggota } \\
\text { Yayasan Bukit Zion }\end{array}$ & 20 \\
$\begin{array}{l}\text { Kepala sekolah dan guru-guru TK } \\
\text { Zion } \\
\text { Alumni TK Zion }\end{array}$ & 12 \\
\hline Jumlah Total & 42 Orang \\
\hline
\end{tabular}

Analisis Interpretasi Data 
Pertanyaan-pertanyaan yang diajukan dalam angket terbuka ini terbagi dalam dua kategori besar, yaitu: pertanyaan mengenai kurikulum TK Zion dan hubungan antara gereja dan sekolah dalam hal ini GKKAUP dan TK Zion. Hubungan antara gereja penyelenggara dan TK Zion adalah untuk mengetahui peranan TK Zion bagi pertumbuhan gereja dalam hal ini adalah GKKA-UP.

Pertanyaan yang membahas mengenai kurikulum TK Zion adalah kurikulum yang berisi aspek nilai-nilai moral dan agama. Khusus dalam pembahasan mengenai kurikulum, pertanyaan-pertanyaan yang diberikan adalah pertanyaan mengenai mata pelajaran yang diajarkan dan kegiatan belajar mengajar (KBM) yang berhubungan dengan aspek nilai-nilai moral dan agama (lihat lampiran angket terbuka).

\section{Kurikulum TK Zion}

Pertanyaan mengenai ruang lingkup kurikulum TK Zion yang berisi aspek nilai-nilai moral dan agama diajukan kepada penyelenggara, pelaksana dan pengguna. Ada dua jenis pertanyaan yang menyangkut soal kurikulum, yaitu mengenai mata pelajaran yang diajarkan dan juga mengenai KBM yang dilakukan untuk mengembangkan aspek nilai-nilai moral dan agama ini.

Bagi penyelenggara, pertanyaan mengenai kurikulum terdapat pada pertanyaan nomor 7 (tujuh). Pertanyaan mengenai kurikulum kepada pihak penyelenggara hanya 1 buah yaitu mengenai mata pelajaran yang perlu ditambahkan bagi kurikulum yang telah ada dari pemerintah, karena kepada pihak penyelenggara penekanannya adalah hubungan gereja dan sekolah termasuk dukungan dan kontribusi sekolah bagi gereja dan atau sebaliknya. Pada pihak pelaksana, pertanyaan yang membahas mengenai kurikulum yang menyangkut mata pelajaran terdapat pada pertanyaan nomor 1 (satu), 2 (dua) dan 4 (empat). Bagi pihak pengguna, pertanyaan mengenai kurikulum yang berhubungan dengan mata pelajaran yang menyangkut aspek nilai-nilai moral dan agama terdapat pada pertanyaan nomor l (satu).

Pertanyaan yang ditujukan kepada pihak penyelenggara mengenai mata pelajaran yang dapat ditambahkan ke dalam kurikulum TK Zion selain kurikulum dari pemerintah, seperti pengembangan karakter. Pihak penyelenggara menyetujui bahwa pengembangan karakter perlu dimasukkan dalam program pengajaran dan kurikulum TK Zion. Mata pelajaran pengembangan karakter yang dimaksud adalah karakter Kristiani dan sesuai dengan kebenaran Firman Tuhan. Dari pihak gembala sidang sendiri yang adalah mantan koordinator penginjil sekolah menjelaskan lebih lanjut bahwa pengembangan karakter yang perlu dipelajari harus diselaraskan dengan pelajaran agama atau menjadi bagian dari pelajaran agama (Kristen). Pertanyaan yang sama diajukan 
kepada pihak pelaksana (pertanyaan nomor 4). Rupanya dalam pelaksanaan di lapangan, mata pelajaran yang ditambahkan ke dalam kurikulum TK Zion bukanlah pengembangan karakter melainkan mata pelajaran bahasa asing. Dalam wawancara untuk mengetahui lebih dalam alasan mengapa murid TK Zion sudah belajar bahasa asing, 2 orang guru termasuk kepala sekolah menyatakan bahwa mata pelajaran pengembangan karakter telah dimasukkan sebagai salah satu materi dalam pelajaran agama, namun pihak pelaksana mengakui bahwa materi mengenai pengembangan karakter hanya memiliki porsi yang sedikit dalam pelajaran agama. Sedangkan mata pelajaran bahasa asing yaitu bahasa Inggris dan bahasa Mandarin dimasukkan sebagai mata pelajaran tambahan dalam kurikulum TK Zion dengan alasan permintaan pihak pengguna TK Zion dalam hal ini adalah orang tua murid. ${ }^{18}$ Pihak pengguna menginginkan bila murid-murid sudah bisa belajar mengenal bahasa asing sejak usia dini sehingga mudah untuk menyesuaikan pelajaran bahasa ketika berada dalam pendidikan yang lebih tinggi yaitu pendidikan Sekolah Dasar (SD). Alasan yang lain adalah karena sekolahsekolah yang lain pada tingkatan TK telah memberikan pengajaran bahasa asing yaitu bahasa Inggris dan Mandarin kepada muridmuridnya. Bila TK Zion tidak melakukannya maka pihak orang tua murid menganggap bahwa murid-murid tersebut akan tertinggal dari sekolah yang lain. ${ }^{9}$ Pihak pelaksana juga menjelaskan bahwa TK Zion memasukkan semua bidang pengembangan, yaitu 5 lingkup pengembangan dalam kurikulumnya, termasuk aspek nilai-nilai moral dan agama (pertanyaan nomor 1 ).

Mengenai mata pelajaran apa saja yang berhubungan dengan nilainilai moral dan agama, baik pihak pelaksana maupun pihak pengguna sepakat bahwa pendidikan agama adalah mata pelajaran yang mengembangkan aspek nilai-nilai moral dan agama. Namun pihak pengguna memberikan penjelasan tambahan bahwa pengembangan aspek nilai-nilai moral dan agama sangat terasa dalam KBM TK Zion bukan hanya dalam pelajaran agama. ${ }^{20}$

Bagian kedua dari kurikulum TK Zion adalah mengenai KBM yang mengembangkan aspek nilai-nilai moral dan agama. Pertanyaanpertanyaan mengenai KBM yang dilakukan untuk mengembangkan aspek nilai-nilai moral dan agama ditujukan kepada pihak pelaksana dan pengguna. Kepada pihak pelaksana, pertanyaan yang berhubungan

\footnotetext{
${ }^{18}$ Yoseo Fatimah (Kepala Sekolah), Wawancara oleh Penulis, 25 Mei 2012. Hal senada juga disampaikan oleh Desi Nelly Kaya (Guru), 11 Mei 2012.

${ }^{19}$ Dua Orang tua murid (tidak bersedia disebutkan namanya), Wawancara oleh Penulis 31 Mei 2012. Hal senada juga dijelaskan oleh Kepala Sekolah TK Zion, Wawancara oleh Penulis, 25 Mei 2012.

${ }^{20}$ Ibid.
} 
dengan KBM adalah pertanyaan nomor 3 (tiga), 5 (lima), 6 (enam), 7 (tujuh), 9 (sembilan), 10 (sepuluh) dan 11 (sebelas). Sedangkan kepada pihak pengguna, pertanyaan mengenai KBM terdapat pada pertanyaan nomor 2 (dua), 3 (tiga), 4 (empat), 6 (enam), 7 (tujuh), 9 (sembilan) dan 10 (sepuluh).

KBM yang berhubungan dengan aspek nilai-nilai moral dan agama menurut pihak pelaksana dan pengguna adalah ibadah. Ibadah bukan saja dilakukan rutin setiap minggu oleh seluruh murid dan dipimpin oleh guru dan pembicara yang telah ditetapkan oleh bidang kerohanian sekolah tetapi juga ibadah dalam kelas masing-masing. Biasanya ibadah ini dipimpin oleh guru kelas. Respon terhadap ibadah dan cerita Alkitab yang disampaikan menurut pihak pelaksana dan pengguna dalam hal ini adalah alumni menarik dan senang mendengarkan dan mengikuti ibadah dan cerita Alkitab yang disampaikan. Pihak pelaksana menilai dari respon yang diberikan oleh murid-murid yaitu mereka dapat menjawab pertanyaan yang disampaikan sehubungan dengan cerita Alkitab dan duduk dengan penuh perhatian. Seorang alumni mengakui bahwa ketika mengikuti kegiatan kerohanian pada saat itu belum mengerti dan hanya mengikut saja kegiatan-kegiatan tersebut.

Mengenai respon soal keselamatan pribadi, pihak pelaksana dan pengguna mengakui bahwa murid memberikan respon dengan menjawab "ya". Guru-guru agama (dua orang) dan Kepala Sekolah memberikan penjelasan bahwa murid yang mengakui menerima Kristus mendapatkan bimbingan lanjutan. Dari pihak pengguna mengakui menerima keselamatan bagi mereka tidak terjadi ketika berada dalam pendidikan TK.

Perayaan hari-hari besar keagamaan (Kristen) dan melibatkan anak-anak dalam perayaan tersebut juga dilakukan oleh pihak pelaksana yaitu guru-guru. Guru-guru mempersiapkan ibadah dan perayaan harihari besar keagamaan dengan melibatkan murid-murid untuk mengisi acara dan juga terjun langsung dalam latihan persiapan. Hal ini juga diakui oleh pihak pengguna, yaitu alumni dan orang tua murid. ${ }^{21}$ Bukan hanya melibatkan murid dalam perayaan dan ibadah hari-hari besar keagamaan, namun juga pelayanan sederhana dalam ibadah mingguan dan ibadah dalam kelas, seperti memimpin doa singkat atau membawa persembahan.

Suasana PBM dan KBM di TK Zion cukup akrab. Guru-guru melakukan penyambutan setiap awal pelajaran dengan memberikan salam kepada murid dan juga kepada orang tua murid. Dari pihak pengguna, yaitu alumni (5 orang) menyatakan bahwa mereka masih

\footnotetext{
${ }^{21}$ Ibid.
} 
saling berhubungan di antara alumni TK Zion bahkan juga dengan guruguru TK Zion yang pernah mengajar mereka.

Pertanyaan kepada pihak pengguna saja adalah mengenai perubahan sikap dan perilaku yang terjadi ketika mengikuti pendidikan di TK Zion. Pengguna dalam hal ini adalah alumni menyatakan bahwa terjadi perubahan sikap akibat pengajaran yang diberikan berulangulang dan setiap saat. Orang tua murid juga mengakui adanya perubahan sikap pada diri anak mereka, khususnya dalam hal ibadah seperti berdoa dan ke Sekolah Minggu (SM). ${ }^{22}$

\section{Hubungan Gereja dan Sekolah}

Hubungan gereja dan sekolah yang terutama adalah bagaimana peranan PAUD yaitu TK Zion bagi pertumbuhan gereja dalam hal ini GKKA-UP. Selain itu dalam beberapa pertanyaan yang diberikan kepada pihak penyelenggara juga ditanyakan mengenai kontribusi dan dukungan gereja bagi penyelenggaraan TK Zion.

Pihak penyelenggara sepakat bahwa tujuan pendirian TK Zion adalah sebagai tempat untuk mencerdaskan bangsa, khususnya anakanak dari kalangan Tionghoa (5 responden) dan sebagai tempat untuk memperkenalkan Kristus kepada murid sejak mereka masih usia dini (seluruh responden). Jadi pihak penyelenggara sepakat bahwa TK Zion didirikan dengan maksud untuk memperkenalkan Kristus kepada anak sejak usia dini (pertanyaan nomor 1 ).

Mengenai bantuan gereja bagi TK Zion, pihak penyelenggara menjawab bahwa gereja memberikan bantuan dalam penyediaan sarana yaitu gedung sekolah dan tenaga hamba Tuhan yang melayani sebagai penginjil sekolah (pertanyaan nomor 2). Dengan demikian dapatlah dipastikan bahwa hubungan gereja dan sekolah berjalan dengan baik, khususnya dalam bidang kerohanian, melalui tenaga hamba Tuhan gereja yang melayani di TK Zion. Gembala sidang dan pihak yayasan juga menyampaikan harapan bahwa TK Zion dapat menjadi perpanjangan tangan gereja menjangkau murid-murid yang masih berusia dini (pertanyaan nomor 3).

Ada 3 pertanyaan yang berhubungan dengan pertumbuhan gereja yaitu pertanyaan nomor 4 (empat), 5 (lima) dan 6 (enam). Dari pihak pelaksana, pertanyaan yang berhubungan dengan pertumbuhan gereja, yaitu mendorong anak ke SM terdapat pada pertanyaan nomor 8 (delapan). Dan pada pihak pengguna adalah pertanyaan nomor 5 (lima). Pihak pelaksana menyatakan bahwa guru-guru telah mendorong muridmurid untuk menghadiri ibadah di SM pada hari Sabtu, agar murid dapat hadir di SM pada hari Minggu berikutnya. Pihak pengguna juga

\footnotetext{
${ }^{22}$ Ibid.
} 
mengakui bahwa guru-guru mendorong mereka untuk menghadiri ibadah SM, dengan cara menghimbau dan mengingatkan untuk menghadiri ibadah SM. Bahkan seorang alumni menyatakan bahwa dorongan yang diberikan berkesan memaksa anak. Hal ini berarti bahwa guru-guru telah berusaha keras untuk mendorong anak menghadiri ibadah SM. Gereja yaitu penyelenggara TK Zion pun mengakui bahwa sekolah telah memberikan kontribusi besar bagi pertumbuhan gereja, mulai dari murid yang menghadiri ibadah SM, juga orang tua murid pun dapat tertarik mengikuti ibadah karena anak mereka yang hadir di SM. Pihak penyelenggara juga menjawab bahwa murid-murid ini dapat menjadi generasi penerus gereja dan mengharapkan melalui mata pelajaran Agama dan pengembangan karakter yang diberikan serta KBM yang bernuansa rohani akan memberikan kesadaran kepada anak untuk memiliki kebiasaan hidup suka beribadah dan menyembah Tuhan.

\section{Hasil Analisis}

Dari hasil angket terbuka yang telah dianalisis secara kualitatif, maka penulis menyimpulkan beberapa hal yang juga merupakan perbandingan dari kurikulum TK Zion dan KBM yang dilakukan bagi murid-murid TK Zion dan dapat mendukung strategi pertumbuhan gereja penyelenggaranya. Untuk kajian isi dari pelaksanaan isi kurikulum dapat disimpulkan sebagai berikut:

Pertama, telah ada cara menolong anak untuk menyadari kebutuhan akan pengampunan dosa dan keselamatan pribadi. Anak akan dibawa kepada pertobatan pribadi dan menerima Yesus sebagai Juruselamat pribadi mereka.

Kedua, sangat memadai tentang anak percaya bahwa dunia dan segala isinya adalah ciptaan Tuhan. dari pembelajaran PAK dan mata pelajaran yang lain mereka dapat mengenal tentang pemahaman ini.

Ketiga, sudah ada pengajaran atas pengenalan bahwa dunia adalah ciptaan Tuhan, anak akan belajar menjaga kebersihan lingkungan dan mengurusnya serta memperlakukan hewan dengan baik.

Keempat, ada praktika di mana anak suka memuji Tuhan dan melakukannya dengan sungguh-sungguh. Guru dapat mengajarkan lagu-lagu pujian dengan menarik serta menjelaskan makna dari lagu tersebut.

Kelima, pelajaran guru juga mendorong anak suka pergi beribadah ke gereja. Sekolah dapat menyiapkan ibadah sekolah juga yang menarik. Dengan cara ini anak dapat tertarik untuk beribadah di SM dan di gereja. Dengan sekolah menyiapkan ibadah khusus, maka anak akan belajar menjadikan ibadah komunitas dan pribadi sebagai nilai utama dalam hidupnya. 
Keenam, selain dari ibadah dalam komunitas, anak juga didorong untuk melakukan ibadah pribadi. Mungkin sekolah dapat menyiapkan renungan harian anak yang khusus untuk anak TK. Dalam renungan pribadi mereka dapat belajar berdoa dan akhirnya anak akan hidup bergantung kepada kuasa doa.

Ketujuh, adanya kegiatan dalam merayakan hari-hari raya keagamaan (Kristen), seperti Natal dan Paskah. Ibadah ini dirancang khusus dan lebih istimewa dari ibadah rutin sekolah. Dalam perayaan ibadah khusus ini dapat dijelaskan makna atau arti mengapa merayakan ibadah khusus ini, sehingga diharapkan kelak anak bukan melakukannya sebagai rutinitas tetapi mereka dapat menghargai makna setiap hari-hari raya ini.

Kedelapan, tentang keterlibatan anak dalam ibadah sekolah atau ibadah-ibadah khusus seperti perayaan Natal dan Paskah, ternyata juga melibatkan anak untuk mengisi acara seperti persembahan pujian, bermain drama, dan lain sebagainya. Hal ini akan memupuk sikap pelayanan dalam kehidupan bergereja atau beribadah. Ketika melibatkan mereka, perlu juga penjelasan mengapa mereka terlibat dalam aktifitas tersebut, sehingga anak dapat mengerti apa arti pelayanan dan memiliki hati pelayan.

Kesembilan, guru telah menjadi teladan dalam perilaku baik dan sopan di antara sesame guru dan karyawan sehingga anak-anakpun dengan lebih mudah dapat melakukannya. Perilaku baik dan sopan adalah penerapan hidup orang Kristen yaitu menghasilkan buah-buah Roh dan karakter Kristus sebagai hasil dari pertobatan dan perjumpaan pribadi dengan Kristus.

Kesepuluh, belajar mengasihi Tuhan dan sesama manusia seperti diri sendiri. Dengan mengasihi Tuhan dengan sepenuh hati, tidaklah sulit untuk mengasihi sesama manusia. Ketika mengasihi sesama manusia seperti diri sendiri, akan muncul sikap menghargai perbedaan, menghormati teman, mau berbagi dan bekerja sama, suka menyapa, dapat mengucapkan terima kasih kepada orang lain yang memberikan sesuatu serta sikap-sikap terpuji yang lain sebagai wujud kasih kepada Tuhan dan sesama.

Kesebelas, menghormati orang tua yang adalah perintah Tuhan. Anak akan menghormati orang tua dan guru juga menghormati otoritas yang lain seperti polisi di jalan. Sikap ini dipupuk melalui pengajaran di ruang kelas, dalam ibadah dan teladan hidup sehari-hari. Misalnya memberi salam dan menyapa antara guru dan murid atau sebaliknya.

Keduabelas, menghidupkan suasana rohani yang kental dalam PBM dan KBM di sekolah. Seperti membiasakan berdoa sebelum dan sesudah kegiatan, menganjurkan dan atau menghimbau anak setiap akhir minggu untuk menghadiri ibadah di gereja esoknya. 
Beberapa poin di atas dapat dilakukan oleh TK Kristen sebagai strategi pembelajaran dalam menolong pertumbuhan iman anak dan mendorong mereka mengikuti ibadah gereja maupun ibadah pribadi dengan setia. Sedangkan untuk analisis pembahasan pelaksanaan, ternyata walaupun dianggap penting pelajaran agama dan pengembangan karakter, namun dalam pelaksanaannya pelajaran ini mendapatkan alokasi waktu yang sedikit dibandingkan dengan pelajaran lainnya. Maka ada dualisme antara keyakinan tentang pentingnya agama dan praktik pelaksanaannya. Ini yang kemudian membawa hasil yang tidak optimal bagi pertumbuhan gereja bila hal ini tidak diberikan jalan keluarnya.

\section{PENUTUP}

\section{Kesimpulan}

Pertama, gereja dapat bertumbuh melalui dua cara, yaitu penginjilan dan pemuridan. Penginjilan adalah pemberitaan kabar baik kepada orang yang belum percaya kepada Tuhan Yesus agar mereka menjadi percaya dan kemudian menjadi anggota tubuh Kristus, yaitu gerejaNya. Pemuridan adalah pengajaran bagi orang-orang percaya agar mereka bertumbuh dan berfungsi dengan baik sebagai anggota tubuh Kristus. Penyebab pertumbuhan adalah kuasa Roh Kudus. Manusia yang telah menjadi anggota tubuh Kristus terpanggil untuk membuat gereja bertumbuh dengan kuasa dan pekerjaan Roh-Nya. Kedua, ada berbagai metode pertumbuhan gereja melalui penginjilan. Salah satunya adalah melalui sarana pendidikan formal, yaitu sekolah yang diselenggarakan oleh gereja. Sekolah dapat digunakan sebagai sarana dan strategi pertumbuhan gereja. Begitu banyak murid-murid yang mengikuti pendidikan yang dapat dijangkau bagi Kristus dan menjadi anggota tubuh Kristus. Ketiga, PAUD pada jenjang pendidikan formal yaitu TK, dalam hal ini TK Kristen yang diselenggarakan oleh gereja lokal dapat dijadikan sebagai salah satu strategi bagi pertumbuhan gereja. Keempat, anak usia dini yang mengikuti pendidikan TK, yaitu usia 4-6 tahun adalah ladang misi yang luar biasa. Karakteristik murid TK sangat terbuka terhadap pengajaran tentang kasih Yesus/Allah. Suka mengikuti kebaktian, dapat belajar berdoa, dapat belajar tentang Allah melalui kebaktian dan terbuka terhadap contoh dan teladan tentang iman Kristen melalui orang dewasa. 


\section{KEPUSTAKAAN}

Buku dan Diktat

Asmani, Jamal Ma'mur. Manajemen Strategis Pendidikan Anak Usia Dini. Yogjakarta: DIVA Press, 2009.

Ayuningsih, Dyah. Psikologi Perkembangan Anak. Yogyakarta:Pustaka Larasati, n.d.

Budiardjo,Tri. Anak-anak: Generasi Terpinggirkan? Yogyakarta: ANDI, 2010.

Dever, Mark. Sembilan Tanda Gereja yang Sehat. Surabaya: Momentum, 2010.

Elisabeth. Pembelajaran PAK Pada Anak Usia Dini. Bandung: Bina Media Informasi,

2009.

Jenson, Ron dan Jim Stevens, Dinamika Pertumbuhan Gereja. Malang: Gandum Mas, 2004.

Lim-Tan, Rosalind. "Together for Children Together for Children Training for Trainers" Module. Diktat Kuliah. Penang:MBTS Holistic Child Development Institute, 2011.

Maryatun, Ika Budi dan Nur Hayati, "Pendidikan Profesi Guru Program Pengembangan Pendidikan Anak" dari buku Pengembangan Program PAUD . Yogyakarta:Kementerian Pendidikan Nasional Universitas Negeri Yogyakarta Program Studi Pendidikan Guru PAUD, 2010.

Mutiah, Diana. Psikologi Bermain Anak Usia Dini. Jakarta:Kencana, 2010.

Noorlaila, Iva. Panduan Lengkap Mengajar PAUD.Yogyakarta:PINUS BOOK PUBLISHER, 2010.

Nuhamara, Daniel. Pembimbing PAK. Jawa Barat:Jurnal Info Media, 2007.

Richards, Lawrence. Pelayanan kepada Anak-anak. Bandung: Kalam Hidup, 2007.

Susanto, Ahmad. Perkembangan Anak Usia Dini: Pengantar dalam Berbagai Aspeknya. Jakarta: Kencana, 2011.

Tanya, Eli. Gereja dan Pendidikan Kristen. Cianjur:STT Cipanas, 1999.

Wiersma, William \& Stephen G. Jurgs, Research Methods in Education, Eight ed. USA:Pearson, 2005.

\section{Sumber Internet}

Klassen, Harold. "Kata Siapa Anda Bukan Perintis Jemaat?"; diakses tanggal 3 April 2012; tersedia di http://www.transformingteachers.org/index.php? option=com_content\&task=view\&id=213\& Itemid=143 
Lowijaya, Jonathan. "Pertumbuhan Gereja ditinjau dari sudut Ontologis"; diakses tanggal 2 April 2012; tersedia di http://www.persetia.org/ARTIKEL\%2011.htm.

Pesan Pastoral Sidang KWI 2008, Perihal "lembaga Pendidikan Katolik"; diakses tanggal 3 April 2012; tersedia di http://www.seminarikwi.org/?pilih=news\&mod=yes\&aksi=lihat\&i $\mathrm{d}=19$.

Sairin, Weinata. "Memahami Relasi Gereja dan Sekolah"; diakses tanggal 3 April 2012; tersedia di http://artikel.sabda.org/memaknai_relasi_gereja_dengan_sekolah.

Sejarah GKKA Indonesia Jemaat Ujung Pandang"; diakses tanggal 2 April 2012; tersedia di http://gkkaupg.blogspot.com/2009/05/sejarah-gkkaujungpandang.html

\section{Dokumen/Diktat/Tesis}

Abdiono, Budi. "Sekolah Zion Sebagai Salah Satu Strategi Pengembangan Pelayanan di GKKA Indonesia Jemaat Ujungpandang”, Tesis. Makassar: STT Jaffray, 2011.

Akte Pendirian Yayasan Pendidikan Zion, Gereja Kristen Makassar. Nomor 27, Tanggal 11-11-1969.

Dokumen Sekolah Zion, Tahun 2011.

Dokumen Kurikulum TK Zion, Tahun 2011.

Miller, Geraldine. "Catatan Kuliah Teaching Children in the Church." International School Of Theology - Asia, Manila, 6 Juli 1998.

Peraturan Pemerintah Nomor 19 tahun 2005 tentang Standar Nasional Pendidikan . Sistem Pendidikan Nasional, DEPDIKNAS, 2008 UU No 20 tentang Sisdiknas Tahun 2003

Wawancara:

Yoseo Fatimah (Kepala Sekolah), Wawancara oleh Penulis, 2 April dan 11 Mei 2012.

Dessi Nelly Kaya, Wawancara oleh Penulis, 11 Mei 2012.

Dua orang tua murid (tidak bersedia disebutkan nama), Wawancara oleh Penulis, 25 Mei 2012. 